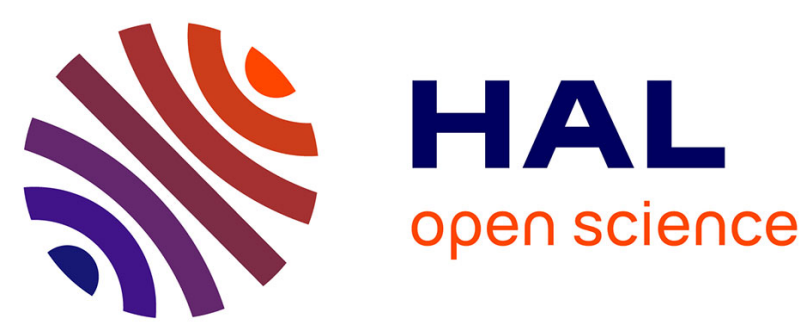

\title{
Disentangling the latitudinal and altitudinal shifts in community composition induced by climate change: The case of riparian birds
}

\author{
Elie Gaget, Vincent Devictor, Bernard Frochot, Régis Desbrosses, \\ Marie-christine Eybert, Bruno Faivre
}

\section{To cite this version:}

Elie Gaget, Vincent Devictor, Bernard Frochot, Régis Desbrosses, Marie-christine Eybert, et al.. Disentangling the latitudinal and altitudinal shifts in community composition induced by climate change: The case of riparian birds. Journal of Biogeography, 2021, 48 (3), pp.526 - 536. 10.1111/jbi.14016 . hal-03424104

\author{
HAL Id: hal-03424104 \\ https://hal.science/hal-03424104
}

Submitted on 18 Nov 2021

HAL is a multi-disciplinary open access archive for the deposit and dissemination of scientific research documents, whether they are published or not. The documents may come from teaching and research institutions in France or abroad, or from public or private research centers.
L'archive ouverte pluridisciplinaire $\mathbf{H A L}$, est destinée au dépôt et à la diffusion de documents scientifiques de niveau recherche, publiés ou non, émanant des établissements d'enseignement et de recherche français ou étrangers, des laboratoires publics ou privés. 


\title{
Disentangling the latitudinal and altitudinal shifts in community composition induced by climate change: The case of riparian birds
}

\author{
Elie Gaget ${ }^{1,2,3}$ (D) | Vincent Devictor ${ }^{4}$ | Bernard Frochot $^{5}$ | Régis Desbrosses ${ }^{6}$ | \\ Marie-Christine Eybert $^{7}$ | Bruno Faivre ${ }^{8}$
}

${ }^{1}$ Department of Biology, University of Turku, Turku, Finland

${ }^{2}$ Institut de recherche pour la conservation des zones humides méditerranéennes, Arles, France

${ }^{3}$ CESCO, UMR7204 MNHN-CNRS-

Sorbonne Université, Paris, France

${ }^{4}$ ISEM UMR 554, Université Montpellier II, Montpellier cedex 05, France

${ }^{5} 8$ rue Montesquieu, Dijon, France

${ }^{6} 12$ rue :Saulx: :Tavanes, Arc/Tille, France

${ }^{7} 8$ rue de :Clairville, Cesson-Sévigné, France

${ }^{8}$ UMR/CNRS 6282 BioGéosciences,

Université de Bourgogne Franche-Comté,

Dijon, France

\section{Correspondence}

Elie Gaget, Department of Biology,

University of Turku, 20014 Turku, Finland.

Email: elie.gaget@gmail.com

Funding information

Etablissement Public Loire; FEDER; Plan

Loire Grandeur Nature

Handiling Editor: Richard Ladle

\begin{abstract}
Aim: This study investigates whether, and how, the composition of riparian bird communities has been affected by climate warming and habitat change. Although these two forces act separately, their respective contributions are rarely examined. Moreover, while the response of a given community may be a function of latitude and altitude, most studies have focused on these gradients separately. Riparian ecosystems are an opportunity to investigate community change along latitudinal and elevational gradients.

Location: France, three major rivers (the Doubs, the Allier and the Loire)

Taxon: Birds.
\end{abstract}

Methods: Drawing upon bird community monitoring data over a period of 31 years (1982-2013, $n=1,286$ point counts), we assessed community adjustment to temperature increase with the Community Temperature Index (CTI), and the homogenization pattern following habitat conversion with the Community Specialization Index (CSI). We evaluated the spatial climatic debt accumulated by communities, and the interaction between CTI and CSI trends. Furthermore, we tested differences in trends for lowland and highland elevations.

Results: Over the study period, the temperature increased by $1.17^{\circ} \mathrm{C}$, and the $\mathrm{CTI}$ by $0.12^{\circ} \mathrm{C}$, which corresponds to a spatial climatic debt of $4.9 \mathrm{~km} /$ year. Lowland communities adjusted to warming but not highland communities, which have experienced a decline in species abundance. CSI trends revealed biotic homogenization in both lowland and highland communities. This finding was uncorrelated with the CTI increase, and is thought to be due to the pressure from land use change on community composition.

Main conclusions: Riparian breeding bird communities have been affected by a temperature increase and, potentially, habitat change. Highland communities are most vulnerable to climate warming. Both climate warming and habitat change appear to have rapidly affected the composition of local communities, with expectable concerns on their diversity and specificity in the long term. 


\section{KEYWORDS}

bird distribution, climate warming, climatic debt, community changes, lag, wetland

\section{1 | INTRODUCTION}

Climate warming is impacting community composition. The effects are seen in both latitudinal and elevational shifts in species distribution (Chen et al., 2011), and a key challenge is to differentiate these effects. Continental and large-scale meta-analyses seek to average effects that may, in fact, differ among biogeographical regions (Chen et al., 2011). Furthermore, many studies are based on administrative zones (national/regional monitoring or atlases) with little ecological or/and biogeographical relevance (e.g. Devictor et al., 2012; Hickling et al., 2006). Few studies have considered both latitudinal and elevational impacts of climate warming on the same group, based on a standardized protocol (but see, Hickling et al., 2006).

A second challenge is to separate the effects of climate warming and habitat change (Gaget et al., 2020). A few studies have explicitly investigated their simultaneous impacts; see, for example, de Frenne et al. (2013), Oliver et al. (2017), Auffret and Thomas (2019), Fourcade et al. (2019) and reviews by Oliver and Morecroft (2014), Sirami et al. (2017), and Williams and Newbold (2019). Yet, changes attributed to climate warming or habitat change can be confounded when they interact (Côté et al., 2016; Oliver \& Morecroft, 2014). For instance, an increase in the abundance of a species that is dependent on a specific habitat and a high temperature could be a consequence of a higher local temperature, local habitat changes or a combination of both (Clavero et al., 2011).

Both climate and habitat change can be assessed by indices that track community responses. The community temperature index (CTI) reflects the relative abundance of species-specific thermal preferences (the species temperature index, STI) within assemblages, and has been shown to be effective in quantifying how, following a temperature increase, warm-dwelling species (with high STI) increase their abundance relative to cold-dwelling species (Devictor et al., 2008). Furthermore, increases in CTI have been shown to be consistent among different taxa (Auffret \& Thomas, 2019; Devictor et al., 2012; Fourcade et al., 2019; de Frenne et al., 2013; Oliver et al., 2017), countries (Devictor et al., 2012), spatial scales (Lindström et al., 2013), and to closely match local temperature variations (Gaüzère et al., 2015). A comparison of CTI and temperature trends makes it possible to measure the potential delay accumulated by the community, that is, the spatial climatic debt (Devictor et al., 2012).

Similarly, the community specialization index (CSI) quantifies the relative abundance of habitat specialists and generalists, based on a species specialization index (SSI) (Devictor et al., 2007). A decrease in CSI is observed when local communities are increasingly composed of generalists (species with low SSI). The study of spatial and temporal CSI trends has revealed that the relative abundance of species with higher tolerance to habitat change has increased over time in both local (Devictor, et al., 2008; Devictor et al., 2007) and regional assemblages (Le Viol et al., 2012). Thus, CSI/CTI trends should be a useful way to determine which factor dominates in the long term (Galewski \& Devictor, 2016). This approach, however, remains to be tested with empirical data that combines elevational and latitudinal gradients of climate warming and land use change, and in areas that are naturally delineated (rather than artificial, administrative zones).

Like almost all ecosystems, riparian ecosystems are simultaneously exposed to climate and habitat change (Capon et al., 2013). In Europe, most riparian landscapes have been deeply affected by human activities since the mid-nineteenth century, and continue to be altered by agricultural and urban pressures (Tockner et al., 2009). Although the influence of habitat structure on riparian bird communities has been well documented (Roché, 1989; Wenger, 1999), there are few longitudinal studies, and effects are generally assessed over a short time-scale or with predictive models (Yabuhara et al., 2015).

Regarding spatial change, the continuous structure of riparian habitats makes it possible to investigate whether communities are affected by warming along an elevational gradient. In Europe, populations of both lowland and highland bird species have declined at a similar magnitude (Lehikoinen et al., 2019), but the role played by climate warming along this gradient remains unclear. Higher temperatures force species to move to a higher location, which reduces their geographical distribution (Huntley et al., 2007) and the size of the local population (Lehikoinen et al., 2019).

In theory, a local change in CTI should closely match a local change in temperature in highland areas (Gaüzère et al., 2017) because species only need to make a small shift in elevation to find cooler temperatures, leading to a null, or small, climatic debt. In lowland areas, however, species must make a greater latitudinal shift to compensate for a local change in temperature, thus there should be a time lag between a local change in CTI and a local change in temperature (Devictor et al., 2012). Moreover, this latitudinal shift is more likely to be obstructed by human activities, which are generally more developed in lowland areas. The theory is illustrated by Bertrand et al. (2011) who reported that, for plant communities, changes in CTI were observed in highland areas, while the response to temperature change was slower in lowland areas. Their findings suggest that lowland communities accumulate greater climate debt than highland communities. However, the theory has never been investigated in the same type of ecosystem for mobile species.

Therefore, this study investigates whether, and how, the composition of riparian bird communities can be related to recent climate warming. We analysed three standardized longitudinal datasets (15, 22 and 31 years) related to riparian communities along three major French rivers. Specifically, we used the CTI/CSI approach to (a) evaluate community adjustment to temperature increase, and the subsequent spatial climatic debt; (b) investigate the biotic homogenization 
response; (c) test the influence of elevation (lowland versus highland) on the observed trend and (d) assess the consequences in terms of population trends. We also determined which species were involved in community changes by computing their contribution to community index trends. We expected to find both CTI and CSI changes over time, and a higher spatial climatic debt in lowland areas, due to the greater distance needed to compensate for a local change in temperature.

(a)

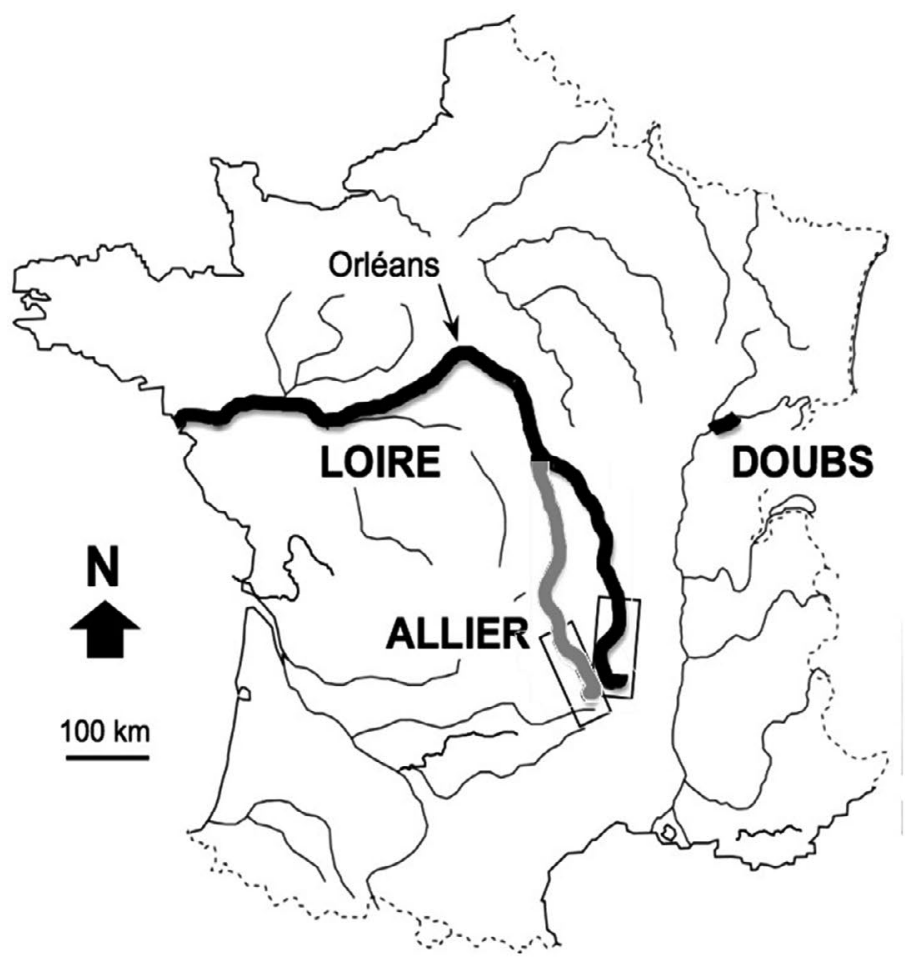

\section{2 | MATERIALS AND METHODS}

\section{1 | River and bird data}

We studied three major French rivers (Figure 1a): the Loire $(1,018 \mathrm{~km})$, the Allier $(415 \mathrm{~km})$ and the Doubs (lower reach only, $50 \mathrm{~km}$ ). Both the Loire and the Allier have significant upstream-downstream gradients, which makes it possible to observe the impact of climate

(b) Elevation (m)

LOIRE

$\mathrm{T}^{\circ} \mathrm{C}$

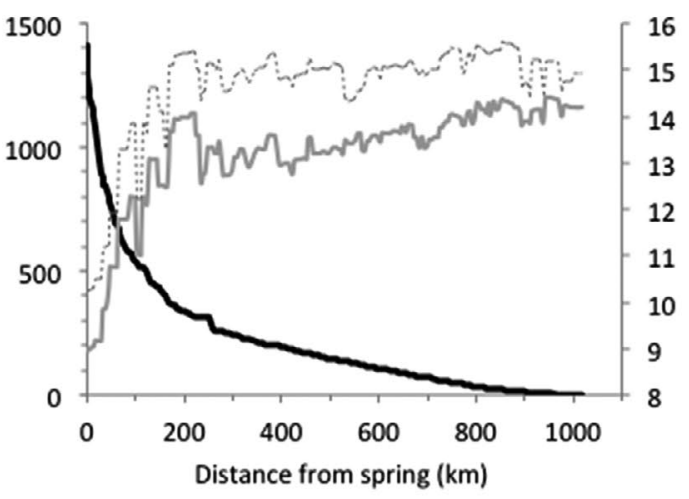

$\begin{array}{lll}\text { Elevation }(m) & \text { DOUBS } & \mathrm{T}^{\circ} \mathrm{C}\end{array}$

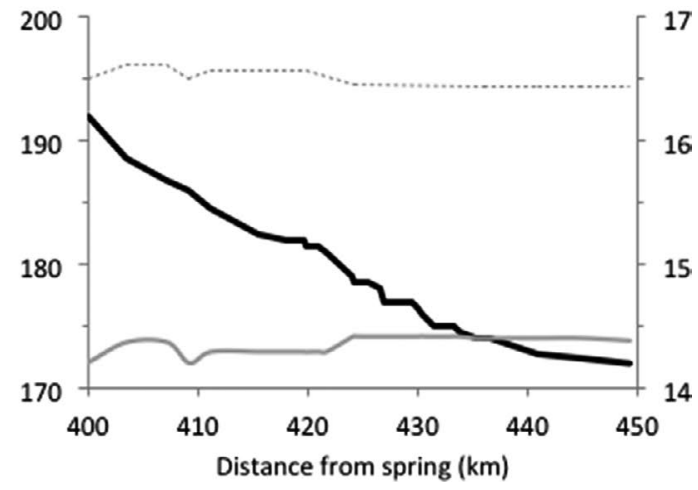

FIGURE 1 (a) Location (in bold) of the sampled river segments in France (the Loire and Doubs are shown in black, the Allier in grey). Rectangles indicate highland areas (elevation $>300 \mathrm{~m}$ ) of the Loire and the Allier. (b) Elevation profiles (black lines) and temperature (grey lines). The bold grey temperature line is the mean for the 6-month breeding season March-August, for the years 1983-1987; the dotted grey temperature line is the mean for the years at the end of each monitoring period (Loire 2007-2011, Allier 2002-2006, Doubs 2008-2013) 
change in very contrasting environments-ranging from subalpine grazed (1,500 $\mathrm{m}$ asl) to floodplains and intensively cultivated areas $(0 \mathrm{~m})$, including continental landscapes with small mountains, forest and hedgerows. All three rivers are characterized by a large, braided and non-channelized low bed (100-400 m wide) surrounded by riparian forest ( $<100 \mathrm{~m}$ wide) in a heterogeneous landscape shaped by strong fluvial dynamics.

Breeding birds were monitored in spring during a longitudinal long-term scientific study that recorded point counts of any species heard or seen (Blondel et al., 1981). Two sessions were run (20 min in April and 20 min between mid-May and mid-June), and the highest abundance for each species between the two sessions was retained. Point counts were regularly spaced along the riverbank (1-5 km depending on the river) to limit the risk of double counting birds moving across a large area, and were strictly identical for each session (Table S1). The final sample consisted of 319 point counts distributed as follows among the three rivers: $n_{\text {Allier }}=90, n_{\text {Loire }}=198$, $\mathrm{n}_{\text {Doubs }}=31$ (Figure 1).

The Loire, Allier and Doubs were monitored, respectively, in 1989-2011, 1991-2006 and 1982-2013. During these periods, the Loire's birds were monitored four times, the Allier's birds three times, and the Doubs's birds 14 times, leading to a dataset of 1,286 bird census counts (Table S1). In total, 174 species were recorded (present at least twice), of which 115 were terrestrial, and 59 were generally considered as aquatic. Only terrestrial species were considered in the analyses. This was because SSI indices are calculated from the French Breeding Bird Survey (FBBS), which is not appropriate for monitoring local, restricted wetland habitats (species are listed in Table S2). Variability associated with observers was limited, as only 12 , experienced ornithologists conducted all censuses, and a given point count was monitored by the same observer, who adopted the same protocol each year.

To estimate the temperature at each local point count position for each year, we used data from the SAFRAN meteorological model (Quintana-Seguí, 2008), which provides mean, monthly 2-m air temperature for an $8 \mathrm{~km} * 8 \mathrm{~km}$ grid over France. These high-resolution data were matched with each point count position for each year, and we then computed the average monthly temperature for the period March-August.

\section{2 | Species indices}

Two main species indices were estimated: the STI and the SSI The STI (species temperature index) is expressed in ${ }^{\circ} \mathrm{C}$ (Devictor et al., 2008) and represents a species thermal preference. It is calculated as the average temperature experienced by a species across its geographical range during the breeding season. STI values were computed from $0.5^{\circ *} 0.5^{\circ}$ temperature grids (April-July averages for the period 1950-2000; WorldClim database) coupled with species Western Palearctic distributions at a $0.5^{\circ}$ resolution, taken from The EBCC Atlas of European Breeding Birds (Hagemeijer \& Blair, 1997) (Table S2). STI values are higher for species that breed in areas with higher temperatures (i.e. southerly distributed) and they have been used in several studies to show the sensitivity of warm- versus colddwellers to climate warming (Jiguet et al., 2010).

The SSI (species specialization index) (Devictor et al., 2007) was calculated for each species. The SSI is the coefficient of variation of the density of that species recorded for 18 habitat classes identified by the FBBS. It thus represents the evenness of the relative abundance of species among habitats, and is understood as a proxy for habitat specialization. Godet et al. (2015) proposed a correction to the index for French avifauna, to account for variation in species commonness. It is to be expected that common species, with wider distribution and/ or larger populations will tend to be found more often in more habitats. Following their method, our raw SSI values were corrected by subtracting the expected SSI from the randomization of habitat classes among FBBS-surveyed plots (Table S2). Consequently, SSI values are higher for species that are concentrated in fewer habitats than predicted by chance.

Finally, as population trends may differ with elevation (Archaux, 2007), species were divided into three elevation classes: 'mountain' ( $n=23)$, 'mountain/plain' ( $n=59)$ and 'plain' ( $n=33$ ) (from Clamens, 2010, see Table S2). Mountain and plain species are highland and lowland specialists, respectively, while mountain/plain species can be found both at lower and higher elevations (Clamens, 2010). It should be noted that STIs for plain species were significantly higher than those for mountain species ( $t$ test, $t_{1,52}=3.51, p<0.001$ ), and mountain/plain species ( $t$ test, $t_{192}=3.05, p=0.004$ ). The difference between mountain and mountain/plain species was not significant ( $t$ test, $t_{1,80}=1.62, p=0.12$ ). SSI values were significantly higher for mountain/plain than mountain species ( $t$ test, $t_{1,80}=-2.15, p=0.04$ ), but no difference was found for the other cases ( $t$ test, $p>0.2$ ).

\subsection{Community-weighted mean trait indices}

Within a community, the aggregated community-weighted mean trait index represents the expected trait value of a randomly sampled community. It is calculated for a given assemblage as the averaged trait value of the species present in this assemblage, weighted by its relative abundance. For each community, and for each monitored year, we calculated the community temperature index $\left(\mathrm{CTI}_{\mathrm{y}, \mathrm{s}}\right.$, based on the STI), and the community specialization index $\left(\mathrm{CSI}_{\mathrm{y}, \mathrm{s}}\right.$, based on the SSI). A given community-weighted mean trait index was then calculated as follows:

$$
C X I_{y, s}=\frac{\sum_{i=1}^{N_{y, s}}\left(A b_{i, y, s} \times S X I_{i}\right)}{\sum_{i=1}^{N_{y, s}} A b_{i, y, s}}
$$

where $C X I_{y, s}$ corresponds to the community-weighted mean trait index based on the trait $X$ (respectively, STI or SSI) of a species (i) recorded at a given point count ( $s$ ) for a given year $(y)$, weighted by their respective abundances at that particular point count and year $\left(A b_{i, y, s}\right)$. Each of these indices was expected to increase following a local, relative increase in individuals belonging to species with higher $X$ values, and/or 
a local, relative decrease in individuals belonging to species with lower $X$ values.

\subsection{Data analysis}

\subsection{1 | Community indices and temperature change}

We used generalized additive mixed-effects models (GAMM) to determine average variation in CTI, CSI and spring temperature over the study period. In the model, the response variable was the point countlevel CTI (or CSI, or temperature) regressed over the years 1982-2013 (expressed as a continuous variable). To avoid any violation of the assumption of independence, we accounted for the influence of spatial gradients among point counts, and temporal autocorrelation among years. We accounted for spatial autocorrelation by fitting point counts' geographical coordinates using a smoothing function (two-dimensional, thin plate regression splines) as a trend-surface of the $Y$ variable (Dormann et al., 2007) according to the method given in Wood (2006). Temporal autocorrelation among years was addressed by adding a temporal (first-order autoregressive function) correlation structure to the model's error term. As a certain amount of variability between point counts (observers, habitat, regional species pool and the specific conditions of each of the three rivers) added uncontrolled variability to the analysis, we allowed for random variation of the intercept on each point count by adding point counts as a random intercept term nested within each river.

This model provided average temporal trends in community indices (CTI and CSI) and temperature for (a) the overall dataset; (b) each river and (c) lowland and highland elevations. Following Malavoi and Gautier (2000), a threshold of $300 \mathrm{~m}$ was set to reflect the geomorphological transition between lowland and highland landscapes for the Loire and the Allier (number of sites; Allier, $n_{\text {Lowland }}=40, n_{\text {High- }}$ land $=50$; Loire, $\mathrm{n}_{\text {Lowland }}=137, \mathrm{n}_{\text {Highland }}=61$ ).

We used the same model to plot year-on-year average change in temperature (with year as a factor), and community indices, accounting for the above-mentioned sources of error, and spatial and temporal non-independence in the error. We then plotted yearly variation in community indices to visually check for potentially nonlinear trends, or a particular year with extreme climatic events.

To assess river-specific trends, the same statistical framework was applied to subsets of the overall dataset, corresponding to the river in question. All analyses used R v.3.4.3 statistical software ( $R$ Core Team 2017), and the nlme (Pinheiro et al., 2014), Ime4 (Bates et al., 2007) and mgcv (Wood, 2015) packages.

\subsection{2 | Independence between CTI and CSI changes}

We assessed whether changes in CTI and CSI impacted the same species. First, we evaluated the correlation between STI and SSI. Second, we tested the relation between species contributions to the trend in CTI, and species SSI. To compute the species contribution to the CTI trend, we used a jack-knife approach to remove each of the 115 species one-by-one, and re-estimated the temporal trend in CTI with the remaining species pool. A comparison of each of the $115 \mathrm{CTI}$ trends with the full species trend gave the contribution of a given species to the temporal trend (Gaget et al., 2020). Finally, we used a linear model to test the relationship between the species contribution to the trend in CTI and species specialization (scaled variables) for the overall dataset, and lowland and highland communities.

\subsection{3 | Climatic debt}

As temperature can increase faster than the CTI (Devictor et al., 2012), we investigated whether there was a spatial lag in communities' adjustment to temperature over the study period. Following the method given in Devictor, et al. (2008), the difference between temperature change and CTI change can be converted into a spatial lag. In France, both temperature and CTI have a decreasing spatial gradient running from south to north; hence, it is possible to estimate and compare spatial shifts in temperature and CTI corresponding to temporal trends. We assumed that the relation between temperature and CTI (Figure S1) and their spatial gradients were similar to observations reported in France by Devictor, et al. (2008). Namely, temperature: $0.45^{\circ} \mathrm{C} \pm 0.07$; CTI: $0.119^{\circ} \mathrm{C} \pm 0.004$ for $100 \mathrm{~km}$

For example, a spatial climatic debt of $150 \mathrm{~km}$ will result from a thermal isocline shift corresponding to $200 \mathrm{~km}$ over 20 years $\left(\left(0.045^{\circ} \mathrm{C} /\right.\right.$ year * 20 year $\left.) /\left(0.45^{\circ} \mathrm{C} / 100 \mathrm{~km}\right)\right)$, and a CTI shift corresponding to only $50 \mathrm{~km}\left(\left(0.003^{\circ} \mathrm{C} /\right.\right.$ year $* 20$ year $\left.) /\left(0.119^{\circ} \mathrm{C} / 100 \mathrm{~km}\right)\right)$ in the same period. We were therefore able to compute the climatic debt (rounded to three decimal places) for the overall dataset, for each river, and for each elevation class (lowland and highland).

\subsection{4 | Species abundance trends}

Finally, we investigated longitudinal trends in abundance for the three elevation classes (plain, mountain/plain and mountain). We assessed the change in abundance in mountain bird species in highland (>300 $\mathrm{m}$ ), the change in abundance in plain bird species in lowland $(<300 \mathrm{~m})$ and the change in abundance in mountain/plain bird species in both lowland and highland. To do that, we used the same GAMM models as previously described (but with a Poisson error distribution and the natural log link function), with abundance as the dependent variable and species as a random effect.

\section{3 | RESULTS}

\subsection{Community indices and temperature change}

During the three decades covered by the study (1982-2013), both temperature and the $\mathrm{CTI}$ increased significantly $\left(\beta=0.037^{\circ} \mathrm{C} /\right.$ year, 
$\beta=0.004^{\circ} \mathrm{C} /$ year, respectively, Table 1 ), although with high annual fluctuations (Figure 2). Conversely, the CSI trend was significantly negative ( $\beta=-0.051$, Figure 2 , Table 1 ). We did not find a correlation between the SSI and STI ( $\left.r_{\text {Pearson }}=0.13, p=0.16\right)$, nor a relationship between species' contribution to the CTI trend and species SSI ( $\beta=0.022 \pm 0.094, p=0.81$ ). The latter findings suggest that climate and habitat changes are not mutually confounding, and act as additive, rather than interactive drivers of community changes.

Considering the three rivers separately, we found a significant increase in both spring temperature and $\mathrm{CTI}$ (temperature, Loire: $\beta=0.026^{\circ} \mathrm{C} /$ year, Allier: $\beta=0.093^{\circ} \mathrm{C} /$ year, Doubs: $\beta=0.037^{\circ} \mathrm{C} /$ year; and CTI, Loire $\beta=0.003^{\circ} \mathrm{C} /$ year, Allier: $\beta=0.004^{\circ} \mathrm{C} /$ year, Doubs: $\beta=0.007^{\circ} \mathrm{C} /$ year, Figure 2 , Table 1). The CSI also declined significantly for all three rivers (Loire: $\beta=-0.051$, Allier: $\beta=-0.050$,

Doubs: $\beta=-0.071$, Figure 2, Table 1).

Although the temperature increased at a similar rate in both lowland and highland areas $\left(\beta=0.043^{\circ} \mathrm{C} /\right.$ year; $\beta=0.041^{\circ} \mathrm{C} /$ year, respectively, Table 1), the $\mathrm{CTI}$ increased significantly in lowland but not highland areas $\left(\beta=0.006^{\circ} \mathrm{C} /\right.$ year; $\beta=0.0001^{\circ} \mathrm{C} /$ year, respectively, Table 1). Over the study period, the CSI decreased significantly in both lowland and highland areas $(\beta=-0.059 ; \beta=-0.049$, respectively, Table 1). We found no relationship between species' contribution to the CTI trend and species SSI in the two altitudinal classes (lowland, $\beta=0.046 \pm 0.094, p=0.62$; highland, $\beta=-0.051 \pm 0.094$, $p=0.59$ ).

TAB LE 1 Changes in temperature, community temperature index (CTI) and community specialization index (CSI) for all data, for each river (Loire, Allier and Doubs) and for lowland and highland elevations (threshold $300 \mathrm{~m}$ )

\begin{tabular}{|c|c|c|c|c|c|}
\hline Data & Variable & $\beta$ & SE & $d f$ & $p$ \\
\hline \multirow[t]{3}{*}{ All } & Temperature & 0.037 & 0.002 & 964 & $<0.001$ \\
\hline & CTI & 0.004 & 0.005 & 964 & $<0.001$ \\
\hline & CSI & -0.051 & 0.009 & 964 & $<0.001$ \\
\hline \multirow[t]{3}{*}{ Loire } & Temperature & 0.026 & 0.003 & 593 & $<0.001$ \\
\hline & CTI & 0.003 & 0.001 & 593 & $<0.001$ \\
\hline & CSI & -0.051 & 0.008 & 593 & $<0.001$ \\
\hline \multirow[t]{3}{*}{ Allier } & Temperature & 0.093 & 0.002 & 179 & $<0.001$ \\
\hline & CTI & 0.004 & 0.002 & 179 & 0.002 \\
\hline & CSI & -0.050 & 0.010 & 179 & 0.003 \\
\hline \multirow[t]{3}{*}{ Doubs } & Temperature & 0.037 & 0.010 & 190 & $<0.001$ \\
\hline & CTI & 0.007 & 0.001 & 190 & $<0.001$ \\
\hline & CSI & -0.071 & 0.010 & 190 & $<0.001$ \\
\hline \multirow[t]{3}{*}{ Lowland } & Temperature & 0.043 & 0.001 & 681 & $<0.001$ \\
\hline & CTI & 0.006 & 0.001 & 681 & $<0.001$ \\
\hline & $\mathrm{CSI}$ & -0.059 & 0.008 & 681 & $<0.001$ \\
\hline \multirow[t]{3}{*}{ Highland } & Temperature & 0.041 & 0.010 & 282 & $<0.001$ \\
\hline & CTI & 0.000 & 0.001 & 282 & 0.890 \\
\hline & CSI & -0.049 & 0.014 & 282 & $<0.001$ \\
\hline
\end{tabular}

\section{2 | Climatic debt}

Overall, the temperature increased faster than the CTI, suggesting that bird communities accumulated a lag in their adjustment (Figure 2). Over the 31 years that elapsed during the study period, the increase in temperature $\left(+1.17^{\circ} \mathrm{C}\right)$ and $\mathrm{CTI}\left(+0.12^{\circ} \mathrm{C}\right)$ correspond to a $255 \mathrm{~km}$ (8.2 km/year) and $104 \mathrm{~km}$ (3.4 km/year) spatial shift in temperature and $\mathrm{CTI}$, respectively. This indicates that breeding birds have accumulated an approximately $151 \mathrm{~km}$ lag over the study period (climatic debt of $4.9 \mathrm{~km} /$ year). The delay estimated for each river corresponded to $3.3 \mathrm{~km} /$ year in the Loire (1990-2011), $17.3 \mathrm{~km} /$ year in the Allier (1991-2006) and $2.3 \mathrm{~km} /$ year in the Doubs (1982-2013). The climatic debt in lowland areas was $4.5 \mathrm{~km} /$ year, compared to $9.0 \mathrm{~km} /$ year in highland areas.

\section{3 | Abundance trends}

Over the study period, no significant abundance trend was observed for plain bird species $(\beta=0.012 \pm 0.010, p=0.19$ ), while a decreasing trend was observed for mountain species $(\beta=-0.119 \pm 0.023$, $p<0.001)$. Mountain/plain species abundance decreased in both lowland $(\beta=-0.034 \pm 0.005, p<0.001)$ and highland $(\beta=-0.042 \pm 0.007, p<0.001)$ areas.

\section{4 | DISCUSSION}

Our longitudinal analysis of change in CTI and CSI in riparian breeding bird communities highlighted an increase in the relative abundance of warm-dwelling and generalist species. This finding is likely to be the result of two ecological drivers that acted simultaneously: temperature change and habitat change. If we assume that the reshuffling of the community corresponds to an adjustment to a warmer climate, the response was slower than the temperature increase, leading to a spatial climatic debt. In addition, although we found no community adjustment to temperature increase in highland elevations, we did observe a general decline in species abundance. Temperature, CTI and CSI trends were fairly similar for all three rivers (Figure 2). Although it is clear that local topographic or environmental variability can affect species assemblages (Gaüzère et al., 2017), overall, the observed community changes suggest that both bird response and environmental constraints were consistent at the broad geographical scale.

\section{1 | An increase in warm-dwelling and generalist species}

This study documents an inferred breeding bird range shift of $3.4 \mathrm{~km} /$ year, which is similar to results at the French $(5.0 \mathrm{~km} /$ year, Gaüzère et al., 2017) and European (2.1 km/year, Devictor et al., 2012) levels. Although we focused on riparian ecosystems, point counts along 

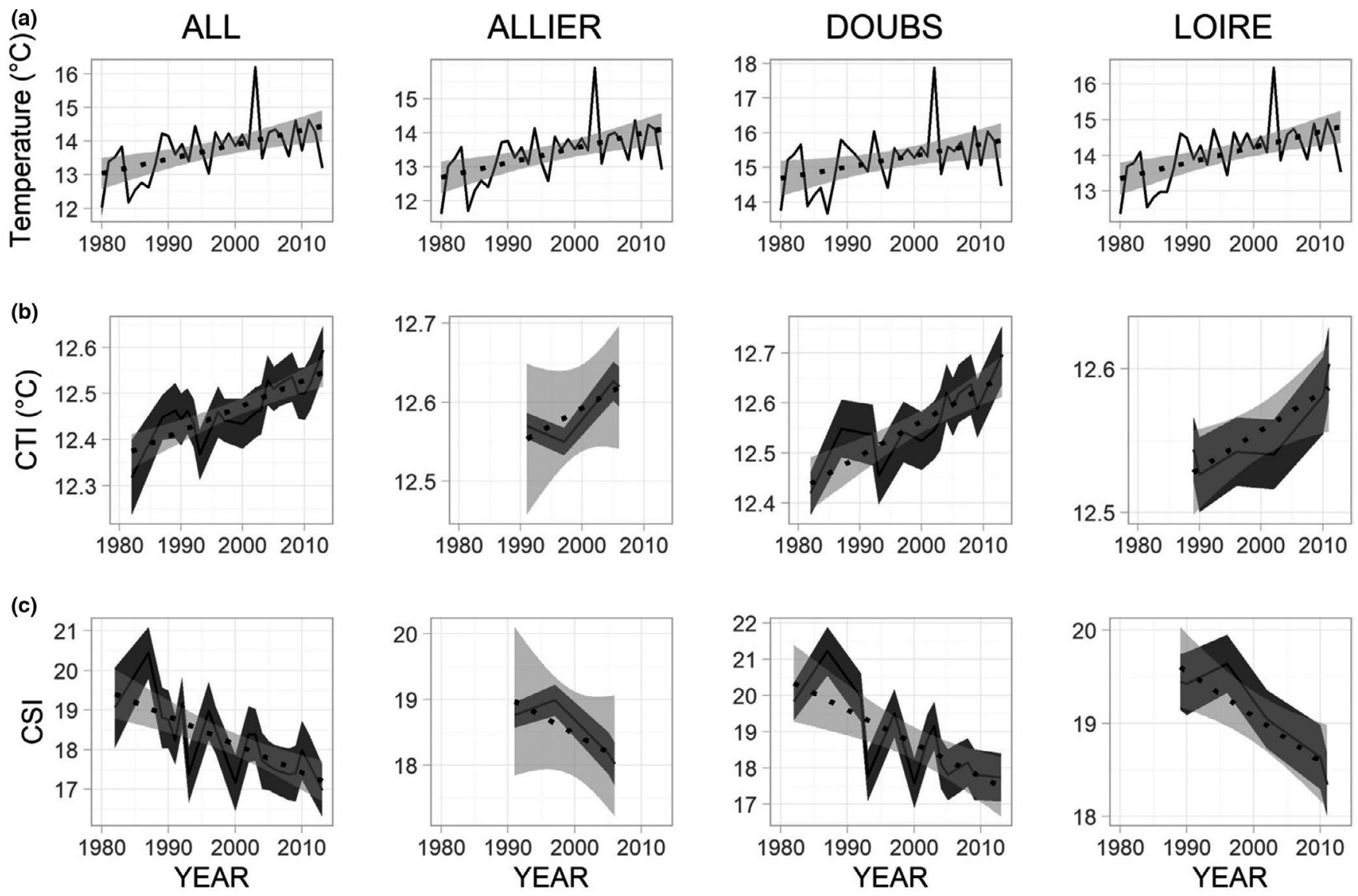

FIGURE 2 Temporal variation along the three sampled rivers (grouped and analysed separately): (a) March to August temperature; (b) the community temperature index (CTI); and (c) the community specialization index (CSI). It should be noted that, nationally, France experienced an anomalous extreme temperature in 2003. The solid line shows the annual, temporal variation for each index (the standard error is shown in dark grey), while the dotted line depicts the temporal trend over the period considered (the standard error is shown in pale grey)

rivers correspond to similar assemblages detected using line transects over other geographical landscapes in France. In addition to river-related species such as Yellow Wagtail (Motacilla flava), other species from more open or closed habitats were fairly common, such as the Skylark (Alauda arvensis) or the Nuthatch (Sitta europaea) (Table S2).

Riparian ecosystems are ecological corridors that support habitat connectivity, and are likely to increase species' movements (Tockner et al., 2009). In our study, the limited number of years sampled for each river (3-14) is likely to have impacted the accuracy of CTI trend measurements. Moreover, other local environmental variables are probably highly heterogeneous among those very different systems. However, our results suggest that the increase in CTI and decrease in CSI are general and consistent tendencies for riparian communities. This result should however be confirmed with additional data conducted on different rivers or groups. Nevertheless, there is no strong evidence of better, or worse, community adjustment to a warming climate in this particular habitat, beyond what has been documented for the overall bird community in France (Gaüzère et al., 2017). This could be related to bird dispersal capacities, or to other ecosystem constraints linked to habitat or topography (Clavero et al., 2011).
Riparian ecosystems are highly vulnerable to land use changes due to human activities (Tockner et al., 2009). The decreasing CSI trend observed in our study is coherent with the biotic homogenization response to land use change, which has been observed in many ecosystems (Clavel et al., 2011). Our study found that the relative increase in generalist species was about 10 times higher than for European breeding birds (Le Viol et al., 2012). This rapid homogenization may indicate significant pressure from habitat change on riparian, and surrounding, breeding bird communities. Riparian habitats concentrate many human activities, as their water resources are used to support agriculture, industry and recreational activities. Threats mainly correspond to the conversion of natural, wetland ecosystems on farmland, or man-made wetlands (Geijzendorffer et al., 2019; Perennou et al., 2018). One example is artificial riverbanks, which humans use to shape stream corridors to prevent flooding hazards. Over time, such pressures can have strong impacts on breeding bird communities, and lead to profound homogenization (Galewski \& Devictor, 2016).

Community-weighted mean trait indices should be used with caution when interpreted as reliable proxies for community changes in response to very specific pressures. Interacting pressures can make it difficult to identify the corresponding trend in community 
composition (Bowler \& Böhning-Gaese, 2017). In general, interactions between drivers of biodiversity changes are synergic (positive correlation with the driver), antagonistic (negative correlation with the driver) or additive (addition without amplification or attenuation) (Côté et al., 2016).

Our study found no correlation between the SSI and the STI, and species contributions to the CTI trend were not related to species specialization. The relative increase in warm-dwelling species was neither positively nor negatively correlated to the relative increase in generalist species. Thus, our results suggest the addition of climate warming and habitat changes, rather than a synergic or antagonistic interaction. At the same time, however, we cannot exclude an interaction for some species. For example, both climate warming and habitat change acting simultaneously could benefit warm-dwelling, generalist species such as the Collared Dove (Streptopelia decaocto) or the Cetti's Warbler (Cettia cetti) whose populations have increased along the Loire and Allier rivers during the past 20 years (Eraud et al., 2007; Roché \& Faivre, 2013). Demographic analyses are required to disentangle the relative effects of climate and riparian ecosystem changes at the species level.

\subsection{Elevation and community changes}

Contrary to earlier work (Bertrand et al., 2011) or previous assessments of breeding birds (Gaüzère et al., 2017), and despite a similar temperature increase in lowland and highland elevations, a community adjustment was detected in lowland but not highland areas. Interestingly, CSI trends were almost identical in the two altitudinal classes, once again suggesting that the factors driving the effects on the CTI and the CSI are independent. Several alternative, nonexclusive hypotheses could explain why the spatial climatic debt accumulated by breeding birds in highland areas was two times higher than in lowland areas.

First, directional habitat change may buffer the impact of climate warming. Increasing afforestation at higher elevations (Lehikoinen et al., 2019) could favour forest and cold-dwelling species. For example, Clavero et al. (2011) found a decrease in the CTI in habitats ranging from open to closed (e.g. from agricultural to forest). The authors argued that this was because the thermal preference of forest species is, on average, lower than the rest of the community, due to their evolutionary history (Blondel, 1990, 2017). It is therefore possible that old forest stands can buffer the negative impact of climate warming on some thermally sensitive species (Betts et al., 2018). However, our study provides little support for this theory, as we found a decline in abundance of mountain species, which is coherent with results at the European level (Lehikoinen et al., 2019).

Second, our study focused on temperature change, but other factors may drive shifts in species distribution. One possibility is precipitation change, which may also explain CTI variation, although to a lesser degree than temperature change (Gaüzère et al., 2015). Investigating the effect of precipitation, and subsequent stream dynamics, would be a highly relevant way to further explore change in the riparian bird community.

Last, it is possible that technical limitations may have affected our results. The spatial resolution we adopted may be insufficient to detect an elevation shift (Hickling et al., 2006), along with the temperature change. Our study used the SAFRAN meteorological model, which is based on measures of temperature for an $8 \mathrm{~km} * 8 \mathrm{~km}$ grid over France. Even this fine-grain resolution may not be accurate enough to reliably capture temperature changes in stream corridors, where micro-climate conditions can form. It is possible that the temperature increase was dampened along these corridors, and masked bird responses.

\section{3 | Conservation implications}

The overall process of homogenization and the spatial climatic debt accumulated by riparian breeding bird communities reveal that human activities can have a negative impact on vulnerable communities. Riparian ecosystems are ecological corridors that are expected to facilitate shifts in species distribution, in response to climate warming (Capon et al., 2013). But our study found no evidence that community adjustment in these corridors was any better than the average French breeding bird community adjustment (Gaüzère et al., 2017). Our results, therefore, question the function of these riparian corridors, at least for birds. Both urbanization and agricultural intensification alter the riparian habitat structure (Tockner et al., 2009)-for example, by reducing the amount of natural vegetation around the river. Increasing riverbank management increases habitat homogenization (Cavaillé et al., 2013). Wetland conservation should be more effective (Finlayson et al., 2019) and based on both land use and climate change considerations (Malek et al., 2018).

Highland ecosystems are particularly vulnerable, and the worrying decline in mountain bird populations highlights their extinction risk under climate warming scenarios (Sekercioglu et al., 2008). Our study found that highland bird communities suffered most, with rapid homogenization, an absence of significant adjustment to climate warming, and species abundance decline. Although our finding is in line with the predicted impact of climate warming (Huntley et al., 2007), it could be attributed to other causes, such as intense land use change due to pastoralism, afforestation or recreational activities (Lehikoinen et al., 2019). Given these pressures, and their consequences for biodiversity, water management policies should be strengthened to enhance riparian conservation and recovery (Tockner et al., 2009). Appropriate landscape management may increase species' resilience to temperature increases (Carroll et al., 2015). More broadly, the role of protected areas in preserving mountainous riparian corridors should be investigated in depth, given their ability to reduce anthropic pressures on ecosystems, and facilitate change in species distribution in response to climate warming (Gaüzère et al., 2016).

Finally, little is known about specific trends in riparian bird populations, and they are needed to assess whether common species 
are declining more quickly or more slowly than at the national or European level (Inger et al., 2015). Overall, our results support the development of longitudinal surveys and conservation actions dedicated to riparian bird communities. Not only are these assemblages among the richest in Europe, but they are also highly exposed to both land use and climate change.

\section{ACKNOWLEDGEMENTS}

This work was supported by the Etablissement Public Loire, the FEDER (FEDER Loire and Interreg IIlc Sud), the Plan Loire Grandeur Nature and the Région Bourgogne. We would like to thank the ornithologists who contributed to bird community monitoring: Jean Roché for his long-term investment and key insights into the development of this study; Jacques Blondel for his invaluable advice; Yves Richard for his climatologist perspective and Nicole Yavercovski for preliminary, quantitative analyses.

\section{DATA AVAILABILITY STATEMENT}

The public data that support the findings of this study are available from the Dryad database (https://doi.org/10.5061/dryad.1rn8p kOrx), the private data (14 Doubs' points counts) are available from the corresponding author on request, and the species-specific values of SSI, STI and elevation class are in Table S2.

\section{ORCID}

Elie Gaget (iD https://orcid.org/0000-0003-3462-9686

\section{REFERENCES}

Archaux, F. (2007). Are mountains refuges for farmland bird species? A case study in the northern French Alps. Bird Study, 54, 73-79. https:// doi.org/10.1080/00063650709461458

Auffret, A. G., \& Thomas, C. D. (2019). Synergistic and antagonistic effects of land use and non-native species on community responses to climate change. Global Change Biology, 25(12), 4303-4314. https:// doi.org/10.1111/gcb.14765

Bates, D., Sarkar, D., Bates, M. D., \& Matrix, L. (2007). The Ime4 package. R package version, 2(1), 74(2), 4303-4314.

Bertrand, R., Lenoir, J., Piedallu, C., Riofrio-Dillon, G., de Ruffray, P., Vidal, C., Pierrat, J. C., \& Gégout, J. C. (2011). Changes in plant community composition lag behind warming in lowland forests. Nature, 479, 517-520.

Betts, M. G., Phalan, B., Frey, S. J., Rousseau, J. S., \& Yang, Z. (2018). Old-growth forests buffer climate-sensitive bird populations from warming. Diversity and Distributions, 24(4), 439-447. https://doi. org/10.1111/ddi.12688

Blondel, J. (1990). Biogeography and history of forest bird faunas in the Mediterranean zone. In A. Keast (Ed.), Biogeography and ecology (pp. 95-107). SPB Academic Publishing.

Blondel, J. (2017). Origin and dynamics of the forest birds of the Northern Hemisphere. In G. Mikusiński, J.-M. Roberge, \& R. J. Fuller (Eds.), Ecology and conservation of forest birds. Cambridge Univ. Press.

Blondel, J., Ferry, C., \& Frochot, B. (1981). Point counts with unlimited distance. Studies in Avian Biology, 6, 414-420.

Bowler, D., \& Böhning-Gaese, K. (2017). Improving the community-temperature index as a climate change indicator. PLoS One, 12(9), e0184275. https://doi.org/10.1371/journal.pone.0184275

Capon, S. J., Chambers, L. E., Mac Nally, R., Naiman, R. J., Davies, P., Marshall, N., Pittock, J., Reid, M., Capon, T., Douglas, M., Catford, J.,
Baldwin, D. S., Stewardson, M., Roberts, J., Parsons, M., \& Williams, S. E. (2013). Riparian ecosystems in the 21st century: Hotspots for climate change adaptation? Ecosystems, 16(3), 359-381. https://doi. org/10.1007/s10021-013-9656-1

Carroll, M. J., Heinemeyer, A., Pearce-Higgins, J. W., Dennis, P., West, C., Holden, J., Wallage, Z. E., \& Thomas, C. D. (2015). Hydrologically driven ecosystem processes determine the distribution and persistence of ecosystem-specialist predators under climate change. Nature Communications, 6, 7851. https://doi.org/10.1038/ncomms8851

Cavaillé, P., Dommanget, F., Daumergue, N., Loucougaray, G., Spiegelberger, T., Tabacchi, E., \& Evette, A. (2013). Biodiversity assessment following a naturality gradient of riverbank protection structures in French prealps rivers. Ecological Engineering, 53, 23-30. https://doi.org/10.1016/j.ecoleng.2012.12.105

Chen, I. C., Hill, J. K., Ohlemüller, R., Roy, D. B., \& Thomas, C. D. (2011). Rapid range shifts of species associated with high levels of climate warming. Science, 333(6045), 1024-1026.

Clamens, A. (2010). Atlas des oiseaux nicheurs d'Auvergne. Ed. Delachaux Et Niestlé.

Clavel, J., Julliard, R., \& Devictor, V. (2011). Worldwide decline of specialist species: Toward a global functional homogenization? Frontiers in Ecology and the Environment, 9(4), 222-228. https://doi. org/10.1890/080216

Clavero, M., Villero, D., \& Brotons, L. (2011). Climate change or land use dynamics: Do we know what climate change indicators indicate? PLoS One, 6, e18581. https://doi.org/10.1371/journal.pone.0018581

Côté, I. M., Darling, E. S., \& Brown, C. J. (2016). Interactions among ecosystem stressors and their importance in conservation. Proceedings of the Royal Society B: Biological Sciences, 283(1824), 20152592. https://doi.org/10.1098/rspb.2015.2592

de Frenne, P., Rodriguez-Sanchez, F., Coomes, D. A., Baeten, L., Verstraeten, G., Vellend, M., Bernhardt-Romermann, M., Brown, C. D., Brunet, J., Cornelis, J., Decocq, G. M., Dierschke, H., Eriksson, O., Gilliam, F. S., Hedl, R., Heinken, T., Hermy, M., Hommel, P., Jenkins, M. A., ... Verheyen, K. (2013). Microclimate moderates plant responses to macroclimate warming. Proceedings of the National Academy of Sciences of the United States of America, 110(46), 18561-18565. https://doi.org/10.1073/pnas.1311190110

Devictor, V., Julliard, R., Clavel, J., Jiguet, F., Lee, A., \& Couvet, D. (2008). Functional biotic homogeneization of bird communities in disturbed landscapes. Global Ecology and Biogeography, 17, 252-261.

Devictor, V., Julliard, R., Couvet, D., \& Jiguet, F. (2008). Birds are tracking climate warming, but not fast enough. Proceedings of the Royal Society B: Biological Sciences, 275, 2743-2748. https://doi.org/10.1098/ rspb.2008.0878

Devictor, V., Julliard, R., Couvet, D., Lee, A., \& Jiguet, F. (2007). The functional homogenization effect of urbanization on bird communities. Conservation Biology, 21, 741-751. https://doi. org/10.1111/j.1523-1739.2007.00671.x

Devictor, V., van Swaay, C., Brereton, T., Brotons, L., Chamberlain, D., Heliölä, J., Herrando, S., Julliard, R., Kuussaari, M., Lindström, Å., Reif, J., Roy, D. B., Schweiger, O., Settele, J., Stefanescu, C., Van Strien, A., Van Turnhout, C., Vermouzek, Z., WallisDeVries, M., ... Jiguet, F. (2012). Differences in the climatic debts of birds and butterflies at a continental scale. Nature Climate Change, 2, 121-124. https://doi. org/10.1038/nclimate1347

Dormann, C., McPherson, J., Araújo, M., Bivand, R., Bolliger, J., Carl, G., Davies, R., Hirzel, A., Jetz, W., Daniel Kissling, W., Kühn, I., Ohlemüller, R., Peres-Neto, P., Reineking, B., Schröder, B., Schurr, F., \& Wilson, R. (2007). Methods to account for spatial autocorrelation in the analysis of species distributional data: A review. Ecography, 30, 609-628. https://doi. org/10.1111/j.2007.0906-7590.05171.x

Eraud, C., Boutin, J.-M., Roux, D., \& Faivre, B. (2007). Spatial dynamics of an invasive bird species assessed using robust design occupancy 
analysis: The case of the Eurasian collared dove (Streptopelia decaocto) in France. Journal of Biogeography, 34, 1077-1086.

Finlayson, C. M., Davies, G. T., Moomaw, W. R., Chmura, G. L., Natali, S. M., Perry, J. E., Roulet, N., \& Sutton-Grier, A. E. (2019). The second warning to humanity-providing a context for wetland management and policy. Wetlands, 39(1), 1-5. https://doi.org/10.1007/s1315 7-018-1064-z

Fourcade, Y., Åström, S., \& Öckinger, E. (2019). Climate and land-cover change alter bumblebee species richness and community composition in subalpine areas. Biodiversity and Conservation, 28(3), 639-653. https://doi.org/10.1007/s10531-018-1680-1

Gaget, E., Galewski, T., Jiguet, F., Guelmami, A., Perennou, C., Beltrame, C., \& Le Viol, I. (2020). Antagonistic effect of natural habitat conversion on community adjustment to climate warming in non-breeding waterbirds. Conservation Biology, 34(4), 966-976. https://doi. org/10.1111/cobi.13453

Galewski, T., \& Devictor, V. (2016). When common birds became rare: Historical records shed light on long-term responses of bird communities to global change in the largest wetland of France. PLoS One, 11(11), e0165542. https://doi.org/10.1371/journal.pone.0165542

Gaüzère, P., Jiguet, F., \& Devictor, V. (2015). Rapid adjustment of bird community compositions to local climatic variations and its functional consequences. Global Change Biology, 21, 3367-3378. https:// doi.org/10.1111/gcb.12917

Gaüzère, P., Jiguet, F., \& Devictor, V. (2016). Can protected areas mitigate the impacts of climate change on bird's species and communities? Diversity and Distributions, 22(6), 625-637. https://doi.org/10.1111/ ddi.12426

Gaüzère, P., Princé, K., \& Devictor, V. (2017). Where do they go? The effects of topography and habitat diversity on reducing climatic debt in birds. Global Change Biology, 23, 2218-2229. https://doi. org/10.1111/gcb.13500

Geijzendorffer, I. R., Beltrame, C., Chazee, L., Gaget, E., Galewski, T., Guelmami, A., Perennou, C., Popoff, N., Guerra, C. A., Leberger, R., Jalbert, J., \& Grillas, P. (2019). A more effective Ramsar convention for the conservation of Mediterranean wetlands. Frontiers in Ecology and Evolution, 7, 21. https://doi.org/10.3389/fevo.2019.00021

Godet, L., Gaüzere, P., Jiguet, F., \& Devictor, V. (2015). Dissociating several forms of commonness in birds sheds new light on biotic homogenization. Global Ecology and Biogeography, 24, 416-426. https://doi. org/10.1111/geb.12266

Hagemeijer, W. J. M., \& Blair, J. M. (Eds.) (1997). The EBCC atlas of European breeding birds. Their distribution and abundance.

Hickling, R., Roy, D. B., Hill, J. K., Fox, R., \& Thomas, C. D. (2006). The distributions of a wide range of taxonomic groups are expanding polewards. Global Change Biology, 12, 450-455. https://doi. org/10.1111/j.1365-2486.2006.01116.x

Huntley, B., Green, R. E., Collingham, Y. C., \& Willis, S. G. (2007). A climatic atlas of European breeding birds. The RSPB and Lynx Editions. Durham University.

Inger, R., Gregory, R., Duffy, J. P., Stott, I., Voříšek, P., \& Gaston, K. J. (2015). Common European birds are declining rapidly while less abundant species' numbers are rising. Ecology Letters, 18(1), 28-36. https://doi.org/10.1111/ele.12387

Jiguet, F., Gregory, R. D., Devictor, V., Green, R. E., Vorisek, P., Van Strien, A., \& Couvet, D. (2010). Population trends of European common birds are predicted by characteristics of their climatic niche. Global Change Biology, 16, 497-505. https://doi. org/10.1111/j.1365-2486.2009.01963.x

Le Viol, I., Jiguet, F., Brotons, L., Herrando, S., Lindström, A., PearceHiggins, J. W., Reif, J. V., Turnhout, C., \& Devictor, V. (2012). More and more generalists: Two decades of changes in the European avifauna. Biology Letters, 8, 780-782. https://doi.org/10.1098/rsbl.2012.0496

Lehikoinen, A., Brotons, L., Calladine, J., Campedelli, T., Escandell, V., Flousek, J., Grueneberg, C., Haas, F., Harris, S., Herrando, S., Husby,
M., Jiguet, F., Kålås, J. A., Lindström, Å., Lorrillière, R., Molina, B., Pladevall, C., Calvi, G., Sattler, T., ... Trautmann, S. (2019). Declining population trends of European mountain birds. Global Change Biology, 25(2), 577-588. https://doi.org/10.1111/gcb.14522

Lindström, A., Green, M., Paulson, G., Smith, H. G., \& Devictor, V. (2013). Rapid changes in bird community composition at multiple temporal and spatial scales in response to recent climate change. Ecography, 36, 313-322. https://doi.org/10.1111/j.1600-0587.2012.07799.x

Malavoi, J. R., \& Gautier, J. N. (2000). La sectorisation d'un cours d'eau : Une méthode de stratification pour l'analyse et la gestion. Séminaire Plan Loire Grandeur nature, Orléans.

Malek, Ž., Verburg, P. H., Geijzendorffer, I. R., Bondeau, A., \& Cramer, W. (2018). Global change effects on land management in the Mediterranean region. Global Environmental Change, 50, 238-254. https://doi.org/10.1016/j.gloenvcha.2018.04.007

Oliver, T. H., Gillings, S., Pearce-Higgins, J. W., Brereton, T., Crick, H. Q. P., Duffield, S. J., Morecroft, M. D., \& Roy, D. B. (2017). Large extents of intensive land use limit community reorganization during climate warming. Global Change Biology, 23(6), 2272-2283. https:// doi.org/10.1111/gcb.13587

Oliver, T. H., \& Morecroft, M. D. (2014). Interactions between climate change and land use change on biodiversity: Attribution problems, risks, and opportunities. Climate Change, 5(3), 317-335.

Perennou, C., Guelmami, A., Paganini, M., Philipson, P., Poulin, B., Strauch, A., \& Geijzendorffer, I. R. (2018). Mapping Mediterranean wetlands with remote sensing: A good-looking map is not always a good map. Advances in Ecological Research, 58, 243-277.

Pinheiro, J., Bates, D., DebRoy, S., \& Sarkar, D.; R Core Team. (2014). nlme: Linear and nonlinear mixed effects models. v 3.1-117.

Quintana-Seguí, P., Le Moigne, P., Durand, Y., Martin, E., Habets, F., Baillon, M., Canellas, C., Franchisteguy, L., \& Morel, S. (2008). Analysis of near-surface atmospheric variables: Validation of the SAFRAN analysis over France. Journal of Applied Meteorology and Climatology, 47, 92-107. https://doi.org/10.1175/2007JAMC16 36.1

R Core Team. (2017). R: A language and environment for statistical computing. Version 3.4.3. R Foundation for Statistical Computing.

Roché, J. (1989). Un gradient écologique : La succession des oiseaux nicheurs le long des cours d'eau. Acta Oecologica/Oecologia Generalis, 10, 37-50.

Roché, J., \& Faivre, B. (2013) Programme STORI (Suivi Temporel des Oiseaux nicheurs en Rivière). Etude de la Loire et de l'Allier sur l'ensemble de leur cours. 3 - Résultats du suivi quantitatif de l'avifaune nicheuse de 1990 à 2012. Université de Bourgogne.

Sekercioglu, C. H., Schneider, S. H., Fay, J. P., \& Loarie, S. R. (2008). Climate change, elevational range shifts, and bird extinctions. Conservation Biology, 22, 140-150. https://doi. org/10.1111/j.1523-1739.2007.00852.x

Sirami, C., Caplat, P., Popy, S., Clamens, A., Arlettaz, R., Jiguet, F., Brotons, L., \& Martin, J.-L. (2017). Impacts of global change on species distributions: Obstacles and solutions to integrate climate and land use: Land-use and climate change integration. Global Ecology and Biogeography, 26(4), 385-394. https://doi.org/10.1111/geb.12555

Tockner, K., Uehlinger, U., \& Robinson, C. T. (2009). Rivers of Europe. Academic Press.

Wenger, S. (1999). A review of the scientific literature on riparian buffer width, extent and vegetation. Office of Public Service \& Outreach Institute of Ecology, University of Georgia.

Williams, J. J., \& Newbold, T. (2019). Local climatic changes affect biodiversity responses to land use: A review. Diversity and Distributions, 26(1), 76-92.

Wood, S. N. (2006). Generalized additive models: An introduction with R. Chapman and Hall/CRC.

Wood, S. (2015). Package 'mgcv'. R package version, 1, 29.

Yabuhara, Y., Yamaura, Y., Akasaka, T., \& Nakamura, F. (2015). Predicting long-term changes in riparian bird communities in floodplain 
landscapes. River Research and Applications, 31, 109-119. https://doi. org/10.1002/rra.2721

\section{BIOSKETCH}

Elie Gaget is broadly interested in community ecology and impacts of global changes on species assemblages. He is currently working as a postdoc at the University of Turku, in Finland. This paper was part of a collaboration led by Bruno Faivre, Université de Bourgogne Franche-Comté, France.

Author contributions: EG, VD and BF conceived the ideas; BF, $\mathrm{RD}, \mathrm{MCE}$ and $\mathrm{BF}$ conducted the fieldwork and collected the data; EG and VD analysed the data; and EG led the writing with contributions of the other authors.

\section{SUPPORTING INFORMATION}

Additional supporting information may be found online in the Supporting Information section.

How to cite this article: Gaget E, Devictor V, Frochot B, Desbrosses R, Eybert M-C, Faivre B. Disentangling the latitudinal and altitudinal shifts in community composition induced by climate change: The case of riparian birds. J Biogeogr. 2021;48:526-536. https://doi.org/10.1111/jbi.14016 